\title{
Procedury KONTROLNE W ORDYNACJI PODATKOWEJ - STAN OBECNY I KIERUNEK ZMIAN
}

\begin{abstract}
Streszczenie. Przedmiotem artykułu jest odpowiedź na pytanie, czy w przypadku proponowanych w ostatnim czasie zmian do zakresu przedmiotowego czynności sprawdzających należy utrzymać obecnie obowiązujący model kontroli przestrzegania przepisów w Ordynacji podatkowej. Zdaniem autora po zbudowaniu spójnej koncepcji zarządzania ryzykiem oraz zdefiniowaniu miejsca i roli kontroli podatkowej jako procesu można zaproponować koncepcję jednej procedury kontrolnej, stanowiącej niejako połączenie (hybrydę) obecnych instytucji prawnych. W artykule zaproponowano ogólną koncepcję jednej procedury kontrolnej, ale składającej się z dwóch odrębnych etapów, przy czym drugi z nich byłby uruchamiany w ściśle określonych sytuacjach. Wskazano również, że przy redagowaniu konkretnych przepisów ustawowych konieczne jest odpowiednie wyważenie interesu podatnika i budżetu państwa tak, aby zagwarantować skuteczne realizowanie dochodów budżetowych, ale zawsze z poszanowaniem praw zobowiązanych.
\end{abstract}

Słowa kluczowe: procedury kontrolne, nowa Ordynacja podatkowa, czynności sprawdzające, kontrola podatkowa

\section{WPROWADZENIE}

W aktualnym stanie prawnym kontrola rzetelności wywiązywania się z obowiązków podatkowych zasadniczo została uregulowana w dwóch ustawach, tj. w Ordynacji podatkowej ${ }^{1}$ - czynności sprawdzające i kontrola

* Ekonomista i prawnik, członek Komisji Kodyfikacyjnej Ogólnego Prawa Podatkowego, doradca podatkowy, wieloletni pracownik organów podatkowych, e-mail: marcin. loboda@mf.gov.pl.

1 Ustawa z dnia 29 sierpnia 1997 r. - Ordynacja podatkowa (tekst jedn. Dz.U. z 2019 r., poz. 900 ze zm.), dalej: o.p. 
podatkowa oraz w ustawie o Krajowej Administracji Skarbowej ${ }^{2}$ - kontrola celno-skarbowa. Istota procedur zawartych w tych ustawach sprowadza się do urzędowego sprawdzenia prawidłowości wykonywania przez zobowiązanych nałożonych na nich przez prawo podatkowe obowiązków, jednakże o tym, jakie przepisy będą miały zastosowanie oraz jaki organ będzie prowadził to postępowanie, decyduje wiele czynników, w tym przede wszystkim wynik analizy ryzyka, zakres kontroli, status zobowiązanego czy rozmiar prowadzonej działalności.

Z założenia podstawowym zadaniem kontroli celno-skarbowej jest wykrywanie i zwalczanie nieprawidłowości na wielką skalę w sytuacji, gdy rozmiary, złożoność i stopień oddziaływania potencjalnie występujących uchybień w sposób istotny wpływają na system bezpieczeństwa finansowego państwa, a dodatkowo zadaniem naczelników urzędów celno-skarbowych powinno być nakierowanie na sprawną realizację działań o wysokim stopniu złożoności ${ }^{3}$. Bez wątpienia pracownicy oraz funkcjonariusze prowadzący kontrolę celno-skarbową zostali bowiem wyposażeni w dodatkowe uprawnienia ${ }^{4}$, a i w samej procedurze, na etapie wszczęcia i zakończenia, można dostrzec wyraźne różnice. Procedury kontrolne zawarte w o.p. a contrario powinny być zatem stosowane w pozostałych przypadkach, chociaż nadal brak wyraźnej normy prawnej rozgraniczającej stosowanie tych, w mojej ocenie, konkurencyjnych instytucji. Istotne jest jednak, że żadna $\mathrm{z}$ nich nie służy bezpośrednio restytucji w przypadku stwierdzonych nieprawidłowości ${ }^{5}$, ponieważ dopiero celem kolejnej, mogącej w praktyce wystąpić procedury (postępowania podatkowego) jest wydanie decyzji określającej wysokość zobowiązania podatkowego w innej wysokości niż wynikające z deklaracji podatkowej złożonej przez podatnika bądź zobowiązania podatkowego, którego podatnik nie zadeklarował' ${ }^{6}$.

Taki kształt procedur służących kontroli przestrzegania przepisów prawa podatkowego oraz zmiany zaproponowane w ostatnim czasie zarówno

2 Ustawa z dnia 16 listopada 2016 r. o Krajowej Administracji Skarbowej (tekst jedn. Dz.U. z 2020 r., poz. 505 ze zm.), dalej: ustawa o k.a.s.

3 Zob. uzasadnienie do ustawy z dnia 16 listopada 2016 r. o Krajowej Administracji Skarbowej.

4 Przykładowo czynności operacyjno-rozpoznawcze dokonywane na podstawie rozdziału 5 ustawy o k.a.s.

5 D. Strzelec, M. Łoboda, Kontrola przestrzegania przepisów podatkowych, Warszawa 2017, s. 84 .

6 Zob. wyrok Naczelnego Sądu Administracyjnego z dnia 13 stycznia 2016 r., sygn. I FSK 1415/14, CBOSA. 
przez Komisję Kodyfikacyjną Ogólnego Prawa Podatkowego (KKOPP) ${ }^{7}$, jak i w trakcie procesu legislacyjnego w zakresie czynności sprawdzających ${ }^{8}$ prowadzą do pytania, czy kształt tych instytucji powinien pozostać taki jak obecnie, a jeśli nie, to jaki ewentualnie ma być kierunek zmian. Za ewolucją modelu kontroli podatkowej i czynności sprawdzających w o.p. przemawiają przede wszystkim modyfikacje zakresu przedmiotowego czynności sprawdzających wprowadzone w trakcie prac legislacyjnych nad n.o.p., tj. uzgodnień wewnątrzresortowych oraz resortowych prowadzonych przez Ministra Finansów. Bez wątpienia żadna $z$ tych procedur prawnych nie może być na siebie "nakładana i uzupełniana”, a zakres przedmiotowy tych instytucji powinien być wyraźnie rozgraniczony. W przeciwnym razie równoległe funkcjonowanie tych dwóch procedur jest nieracjonalne oraz wprowadza nieład prawny w o.p.

\section{DEFINICJE ORAZ ZAKRES PRZEDMIOTOWY CZYNNOŚCI} SPRAWDZAJĄCYCH I KONTROLI PODATKOWEJ

Czynności sprawdzające funkcjonują od samego początku obowiązywania Ordynacji podatkowej uchwalonej w sierpniu 1997 r., gdzie wprowadzono je jako nową instytucję prawną. Z założenia istota tej instytucji sprowadza się do dobrowolnego wyeliminowania uchybień związanych z rozliczeniem zobowiązań podatkowych bez wszczynania kontroli podatkowej czy postępowania podatkowego. Czynności sprawdzające zaliczono do postępowań odrębnych, prowadzonych poza jurysdykcyjnym postępowaniem podatkowym, stanowiących typ postępowania quasi-kontrolnego $^{10}$. Określa się je jako wstępną kontrolę o charakterze formalnym ${ }^{11}$, której istota polega na weryfikowaniu oraz konfrontowaniu informacji

7 Powołana Rozporządzeniem Rady Ministrów z dnia 21 października 2014 r. w sprawie utworzenia, organizacji i trybu działania Komisji Kodyfikacyjnej Ogólnego Prawa Podatkowego (Dz.U. poz. 1471 ze zm.).

${ }^{8}$ Projekt ustawy - Ordynacja podatkowa, druk sejmowy nr 3517/VIII kadencja, dalej: n.o.p.

9 Ordynacja podatkowa. Kontrola realizacji zobowiązań podatkowych, red. R. Dowgier, Białystok 2012, s. 246, passim.

10 Ordynacja podatkowa. Komentarz praktyczny, red. B. Brzeziński, M. Kalinowski, A. Olesińska, Gdańsk 2015, s. 1124.

11 Por. R. Kubacki, Ordynacja podatkowa. Kontrola podatkowa, „Przegląd Podatkowy" 1998 , nr 5, s. 31. 
pochodzących z różnych źródeł ${ }^{12}$, ale jedynie w zakresie wskazanym wyraźnie w przepisach prawa ${ }^{13}$.

Czynności sprawdzające, podobnie jak kontrola podatkowa, prowadzone są wyłącznie $z$ urzędu i z inicjatywy organu podatkowego. Nie są ograniczone czasowo i mogą być podejmowane wielokrotnie, stanowią też najprostszą formę kontaktu organu podatkowego z podatnikiem, a jednocześnie najmniej uciążliwą ${ }^{14}$. Jest to instytucja prawna konkurencyjna wobec postępowania podatkowego oraz kontroli podatkowej.

$\mathrm{Z}$ założenia instytucja ta powinna być zatem traktowana szczególnie przez organy podatkowe jako pewnego rodzaju czynność o charakterze kontrolnym, choć o jasno sprecyzowanym i zawężonym względem innych procedur celu ${ }^{15}$. Istotne jest, aby ze względu na ekonomikę postępowania, czynności sprawdzające, jako najmniej uciążliwe i najmniej czasochłonne zarówno dla zobowiązanego, jak i organów podatkowych, były stosowane w pierwszej kolejności. W przepisach brakuje wyraźnej normy prawnej, która obligowałaby organy podatkowe do takiego postępowania, jednakże pośrednio wynika to z przepisów dotyczących korygowania deklaracji podatkowych ${ }^{16}$.

Zmiany w prawie podatkowym zachodzące od początku lat dziewięćdziesiątych ubiegłego wieku wprowadziły szerokie stosowanie samoobliczenia zobowiązań podatkowych przez wszystkich zobowiązanych ze względu na upowszechnienie w podatkowym prawie materialnym zobowiązań podatkowych powstających $\mathrm{z}$ mocy prawa ${ }^{17}$. Niezbędne stało się wyposażenie organów podatkowych w instrumenty prawne, które pozwolą im na bezkonfliktowe i stosunkowo proste weryfikowanie prawidłowości wywiązywania się z tego obowiązku.

Zagadnienia dotyczące kontroli podatkowej zostały natomiast zawarte w dziale VI o.p. i w przeciwieństwie do przepisów dotyczących czynności sprawdzających były wielokrotnie nowelizowane na przestrzeni lat

12 Wyrok Wojewódzkiego Sądu Administracyjnego w Gdańsku z dnia 4 października 2016 r., sygn. I SA/Gd 671/16, LEX nr 2153758.

13 Zob. art. 272 o.p. oraz art. 656 n.o.p.

${ }^{14}$ Odmiennie stanowisko prezentuje H. Dzwonkowski, Czynności sprawdzające - pomoc czy zagrożenie interesów podatnika, „Fiskus” 2006, nr 13/14, s. 23-27.

15 Zob. D. Strzelec, M. Łoboda, Kontrola przestrzegania..., s. 93.

16 Zob. L. Etel, R. Dowgier, M. Popławski, S. Presnerowicz, W. Stachurski, K. Teszner, Ordynacja podatkowa. Komentarz, Białystok 2017, http://www.lex.pl.

17 S. Babiarz, B. Dauter, R. Hauser, A. Kabat, M. Niezgódka-Medek, J. Rudowski, Ordynacja podatkowa. Komentarz, Warszawa 2017, s. 1365. 
obowiązywania tego aktu prawnego. W ogólnym znaczeniu kontrola polega na obserwowaniu, ustalaniu oraz wykrywaniu stanu faktycznego, porównywaniu rzeczywistości z zamierzeniami, a także występowaniu przeciwko zjawiskom niekorzystnym i sygnalizowaniu właściwym jednostkom o dokonanych spostrzeżeniach bez decydowania jednak o zmianie kierunku działania jednostki kontrolowanej ${ }^{18}$. Pojęcie to jest rozumiane jako badanie przez uprawniony organ zgodności stanu faktycznego ze stanem określonym według danych norm, czyli porównanie stanu istniejącego z wzorcowym według pewnych mierników - kryteriów kontroli ${ }^{19}$. W ramach kontroli dokonuje się wyznaczonych czynności, które określają stan faktyczny danej działalności podmiotu kontrolowanego, a jej zadaniem jest sprawdzenie zgodności między wyznaczonymi zasadami a ich wykonaniem przez przedsiębiorcę ${ }^{20}$. Wyznaczenie można zatem pojmować jako kryteria kontroli podatkowej, które wskazują, w jaki sposób powinna wyglądać dana działalność, rozliczenie podatkowe, tworząc tym samym pożądany stan zobowiązania podatkowego.

Kontrola podatkowa stanowi zatem rodzaj procedury o sformalizowanym charakterze, z wyraźnie oznaczonym momentem wszczęcia oraz zakończenia, a rezultat poczynionych ustaleń kontrolnych znajduje się w dokumencie urzędowym o ściśle określonej treści, czyli w protokole kontroli ${ }^{21}$. Zasadniczo procedura kontroli podatkowej ma na celu sprawdzenie i ocenienie określonej działalności i, co do zasady, nie obejmuje oddziaływania na podmioty kontrolowane. W jej ramach dokonuje się obserwacji, a następnie ustaleń, jak jest i jak powinno byćc ${ }^{22}$ oraz jakie jest zadeklarowane zobowiązanie podatkowe, a jakie powinno być. Z literalnej wykładni przepisów regulujących kontrolę podatkową ${ }^{23}$ wynika, że organ, stosując je, nie bada, czy kontrolowany korzysta z przysługujących mu uprawnień, ale ogranicza się jedynie do ustalenia, czy kontrolowany wywiązuje się z ciążących na nim obowiązków, dzięki czemu rzetelnie deklaruje podstawę opodatkowania oraz prawidłowo oblicza i wpłaca podatek ${ }^{24}$. Kontrola podatkowa może jednak przyczynić się do załatwienia sprawy podatkowej

\footnotetext{
18 J. Starościak, Prawo administracyjne, Warszawa 1975, s. 346.

19 J. Jagielski, Kontrola administracji publicznej, Warszawa 1999, s. 9.

20 J. Wowra, Kontrola podatkowa i skarbowa przedsiębiorców, Warszawa 2007, s. 15.

21 S. Babiarz, B. Dauter i in., Ordynacja podatkowa..., s. 1393.

22 J. Jagielski, Kontrola..., s. 7.

23 Artykuł $281 \$ 2$ o.p.

24 S. Babiarz, B. Dauter i in., Ordynacja podatkowa..., s. 1394.
} 
poprzez zapewnienie zgodności między stanem rzeczywistym a stanem obowiązującym ${ }^{25}$, bez formalnego wszczynania jurysdykcyjnego postępowania podatkowego, poprzez zaakceptowanie jej ustaleń i złożenie korekty deklaracji ${ }^{26}$, czy też złożenie korekty za następne okresy rozliczeniowe.

Pozostawienie instytucji czynności sprawdzających i kontroli podatkowej w obecnym kształcie, czy też w tym zaproponowanym przez Komisję Kodyfikacyjną Ogólnego Prawa Podatkowego ${ }^{27}$, zależy od zakresu przedmiotowego ich stosowania, który w przypadku czynności sprawdzających powinien być jasno sprecyzowany i zawężony względem innych procedur, zakres kontroli podatkowej powinien natomiast stanowić niejako dopełnienie. Brak takiego wyraźnego rozgraniczenia pozbawia sensu równoległe funkcjonowanie w o.p. kontroli podatkowej, a przemawia za wprowadzeniem jednej procedury weryfikacyjnej prowadzonej przez naczelników urzędów skarbowych i organy samorządowe.

Od samego początku funkcjonowania instytucji czynności sprawdzających do końca 2015 r. zakres przedmiotowy był praktycznie niezmieniany i obejmował: 1) zbadanie terminowości składania deklaracji podatkowych oraz przyczyn niezłożenia deklaracji, pomimo istnienia takiego obowiązku; 2) sprawdzanie terminowości wpłacania zadeklarowanych podatków, w tym również pobieranych przez płatników oraz inkasentów; 3) stwierdzenie formalnej i rachunkowej poprawności dokumentów przedstawionych przy składaniu deklaracji lub wpłacaniu podatków; 4) ustalenie stanu faktycznego w zakresie niezbędnym do stwierdzenia zgodności z przedstawionymi dokumentami ${ }^{28}$.

Analiza powyższych przepisów prowadzi zatem do wniosku, że czynności sprawdzające dotyczą przede wszystkim zobowiązanych od szeroko rozumianej strony formalnej, warto jednak zwrócić uwagę, iż w ramach tej instytucji niedopuszczalne jest prowadzenie postępowania dowodowego innymi środkami niż te, które przewidują przepisy działu V o.p. Odesłanie z art. 280 o.p. nie dopuszcza bowiem stosowania przy czynnościach sprawdzających przepisów rozdziału 11 działu IV o.p., czyli prowadzenia postępowania dowodowego na podstawie takich instrumentów prawnych

${ }^{25}$ W Stachurski, Realizacja zobowiązań podatkowych $w$ ramach procedur kontrolnych, seria System prawa finansowego, t. 3: Prawo daninowe, Warszawa 2010, s. 674.

${ }_{26}$ Zob. D. Strzelec, M. Łoboda, Kontrola przestrzegania..., s. 84.

27 L. Etel et al., Nowa ordynacja podatkowa. Z prac Komisji Kodyfikacyjnej Ogólnego Prawa Podatkowego, Białystok 2017, s. 690.

28 Zob. art. 272 o.p. 
jak w postępowaniu jurysdykcyjnym ${ }^{29}$. Ustalenia organów podatkowych udokumentowane w toku czynności sprawdzających mogą stanowić materiał dowodowy w przypadku wszczęcia postępowania podatkowego, zostanie on jednak zweryfikowany w ramach swobodnej oceny dowodów oraz przy czynnym udziale strony.

Z początkiem 2016 r. do katalogu działań objętych czynnościami sprawdzającymi włączono również większość propozycji wskazanych przez Komisję Kodyfikacyjną Ogólnego Prawa Podatkowego ${ }^{30}$. Został on uzupełniony o weryfikację danych i dokumentów przedstawionych przez podatników dokonujących rejestracji podatkowej (art. 272 pkt 5 o.p.) $)^{31}$, co usunęło wątpliwości, czy organy podatkowe w ramach czynności sprawdzających mogły weryfikować rzetelność podmiotów nowo powstałych jeszcze przed złożeniem pierwszej deklaracji. W ostatnim czasie ${ }^{32}$ przedmiotowy katalog został uzupełniony o weryfikację danych i dokumentów przedstawianych przez podmioty dokonujące zgłoszenia rejestracyjnego uproszczonego, o którym mowa w art. 16b ust. 1 Ustawy z dnia 6 grudnia 2008 r. o podatku akcyzowym (art. 272 pkt 6 o.p.) ${ }^{33}$.

W trakcie praclegislacyjnych prowadzonych nad n.o.p. w ramach uzgodnień resortowych oraz międzyresortowych zakres przedmiotowy czynności sprawdzających został jednak uzupełniony o dwa elementy: 1) weryfikację podstawy opodatkowania oraz stwierdzenie formalnej i rachunkowej poprawności dokumentów przedstawionych przy składaniu deklaracji lub wpłacaniu podatków oraz 2) weryfikację prawidłowości sporządzenia remanentu towarów handlowych zarządzonego przez naczelnika urzędu skarbowego w trakcie roku ${ }^{34}$.

Uzupełnienie katalogu zakresu przedmiotowego czynności sprawdzających o weryfikację podstawy opodatkowania budzi jednak poważne kontrowersje. Weryfikacja taka powinna być bowiem prowadzona wyłącznie w ramach kontroli podatkowej lub postępowania podatkowego,

29 S. Babiarz, B. Dauter i in., Ordynacja podatkowa..., s. 1368.

30 L. Etel et al., Nowa ordynacja podatkowa..., s. 690.

31 Artykuł 1 pkt 149 lit. b Ustawy z dnia 10 września 2015 r. o zmianie ustawy - Ordynacja podatkowa oraz niektórych innych ustaw (Dz.U. z 2015 r., poz. 1649).

32 Zob. art. 5 Ustawy z dnia 19 lipca 2019 r. o zmianie ustawy o systemie monitorowania drogowego i kolejowego przewozu towarów oraz niektórych innych ustaw (Dz.U. z 2019 r., poz. 1556).

33 Tekst jedn. Dz.U. z 2019 r., poz. 864 ze zm.

34 Zob. art. 656 projektu ustawy - Ordynacja podatkowa, druk sejmowy nr 3517/ VIII kadencja. 
a wprowadzenie jej do katalogu czynności sprawdzających zachwiało „cienką linię demarkacyjną" między tymi konkurencyjnymi procedura$\mathrm{mi}^{35}$. Zgodnie z wolą właściciela projektu, czyli Ministra Finansów, na tym etapie legislacji weryfikacja podstawy opodatkowania w ramach czynności sprawdzających z założenia miała dotyczyć tylko i wyłącznie podatników nieprowadzących działalności gospodarczej. Literalne brzmienie tego przepisu przeczy jednak temu założeniu ${ }^{36}$ i pozwala prowadzić je w celu weryfikacji podstawy opodatkowania wobec wszystkich zobowiązanych. Wprawdzie w przypadku braku konsensusu co do wysokości zobowiązania podatkowego między zobowiązanym a organem podatkowym niezbędne jest przeprowadzenie postępowania podatkowego i wydanie odpowiedniej decyzji, jednakże zakres przedmiotowy czynności sprawdzających pokrywa się z kontrolą podatkową.

Zakres przedmiotowy kontroli podatkowej jest praktycznie niezmienny od początku funkcjonowania o.p. i został wyraźnie określony poprzez szerokie wskazanie celu kontroli podatkowej, czyli sprawdzenie, czy podatnicy, płatnicy, inkasenci oraz następcy prawni wywiązują się $\mathrm{z}$ obowiązków wynikających $\mathrm{z}$ przepisów prawa podatkowego, czyli zgodnie z definicją zawartą $\mathrm{w}$ art. 3 pkt 2 o.p.: wszelkich obowiązków wywodzonych z przepisów ustaw podatkowych, z przepisów aktów wykonawczych wydanych na ich podstawie, postanowień ratyfikowanych przez Rzeczpospolitą Polską, umów o unikaniu podwójnego opodatkowania oraz innych aktów prawa międzynarodowego i wspólnotowego dotyczących problematyki podatkowej. Należy się przy tym zgodzić, że cel kontroli podatkowej nie ogranicza jej zakresu do sprawdzenia wywiązywania się przez zobowiązanych z obowiązków tylko o charakterze materialnoprawnym, ale również o charakterze proceduralnym. W toku kontroli podatkowej organy podatkowe nie wnikają zatem, czy kontrolowany korzysta z przysługujących mu uprawnień i ograniczają się wyłącznie do badania, czy zobowiązany wywiązuje się z ciążących na nim obowiązków, a w konsekwencji rzetelnie deklaruje podstawę opodatkowania oraz prawidłowo oblicza i wpłaca podatek ${ }^{37}$.

${ }_{35}$ M. Łoboda, Czynności sprawdzające w Ordynacji podatkowej - stan obecny i kierunki zmian, „Procedury Administracyjne i Podatkowe” 2019, nr 6, s. 31.

${ }^{36}$ Ibidem.

37 S. Babiarz, B. Dauter i in., Ordynacja podatkowa..., s. 1394. 
Brak wyraźnego rozgraniczenia zakresu przedmiotowego obydwu procedur w n.o.p. skłania do pytania, czy potrzebne są dwie, z założenia konkurencyjne, procedury służące weryfikacji podstawy opodatkowania. W mojej ocenie po zbudowaniu spójnej koncepcji zarządzania ryzykiem i zdefiniowaniu miejsca i roli kontroli podatkowej jako procesu można zaproponować koncepcję jednej procedury kontrolnej, stanowiącej niejako połączenie (hybrydę) obecnych instytucji prawnych: czynności sprawdzających oraz kontroli podatkowej. Powinna być ona dość elastyczna, a jednocześnie opierać się na podstawowych zasadach ogólnych prawa podatkowego wskazanych $\mathrm{w}$ rozdziale 2 działu I n.o.p. oraz gwarantować zobowiązanym wszelkie prawa procesowe. Ostateczna decyzja o podjęciu danej procedury kontrolnej (na podstawie o.p. czy ustawy o k.a.s.) zawsze należy do organów podatkowych, jednakże wybór trybu oraz jej rozpoczęcie uzasadniać mogą rozmaite informacje uzyskane przez administrację podatkową, w tym związane z prowadzeniem innej kontroli czy postępowania podatkowego u innych podatników, a także otrzymywanie informacji sygnalnych. Często organy podatkowe uzyskują je już w trakcie prowadzenia czynności sprawdzających, kontroli podatkowej czy postępowania podatkowego, co przemawia za elastycznym podejściem do nowej procedury kontrolnej.

Bez wątpienia, jeżeli kontrola podatkowa ma służyć jedynie PR, to wszelkie czynności z udziałem podatnika powinniśmy nazwać kontrolą podatkową, a stwierdzone nieprawidłowości ustalone na poziomie analitycznym poddać działaniom w procedurze kontroli podatkowej, maksymalizując ujawnione kwoty uszczupleń jako wynik działania kontroli. W takim przypadku zmiana modelu procedury kontrolnej w o.p. jest niepotrzebna. Jeżeli jednak kontrola podatkowa ma być jednym ze skutecznych narzędzi zarządzania ryzykiem związanym $\mathrm{z}$ wystąpieniem nadużyć podatkowych, to $\mathrm{w}$ pierwszej kolejności należy stworzyć koncepcję systemu poboru należności podatkowych z jednoczesnym określeniem roli i zadania nowej procedury kontrolnej w tym systemie.

Organy podatkowe zostały wyposażone w narzędzia do przymusowego egzekwowania należnych podatków, takie jak postępowanie podatkowe, egzekucja administracyjna, kontrola podatkowa czy postępowanie karne skarbowe, dla realizacji podstawowego zadania na wypadek 
niewywiązywania się z obowiązków podatkowych lub niewłaściwego ich wypełniania przez podmioty do tego zobowiązane. Zmiana atrybutu narzędzia w odniesieniu do postępowania podatkowego, egzekucji administracyjnej, kontroli podatkowej czy postępowania karnego skarbowego stwarza podstawy do budowy nowoczesnego systemu zarządzania ryzykiem poboru podatków, który daje możliwość racjonalnego ustawienia priorytetów w działaniu organów. Z drugiej strony organy podatkowe są oceniane nie tylko za sprawny pobór podatków, ale również pod kątem minimalizowania kosztów poboru podatków. Umiejętność wykorzystania czynności analitycznych z całą pewnością prowadzi do obniżenia tych kosztów, a jednocześnie pozwala zredukować zidentyfikowane ryzyko.

Analiza funkcjonującego obecnie systemu poboru należności podatkowych na poziomie centralnym wskazuje możliwość systemowego ustawienia dwóch etapów analizy ryzyka wystąpienia nadużyć podatkowych:

a) ryzyko identyfikowane $\mathrm{w}$ odniesieniu do dokumentu rozliczeniowego (deklaracji/zeznania podatkowego czy informacji zawartych w jednolitym pliku kontrolnym ${ }^{38}$ ) - realizowane w całości na poziomie urzędów skarbowych;

b) ryzyko identyfikowane w odniesieniu do podatnika - w zakresie analitycznym realizowane na poziomie centralnym, regionalnym, a w zakresie wykonawczym na poziomie urzędów celno-skarbowych.

Na podstawie takiego podziału można wyodrębnić dwa główne podejścia do roli procedury kontroli w poborze należności podatkowych:

a) model perswazyjno-audytowy, wyznaczający kontroli podatkowej przede wszystkim rolę narzędzia dostarczania informacji o podmiocie i lukach w systemie podatkowym przez pryzmat złożonych dokumentów rozliczeniowych (deklaracja/zeznanie, JPK). Kontrola podatkowa $\mathrm{w}$ takim ujęciu winna być nasycona instytucjami prawnymi niejako „zapraszającymi” do roli rzetelnego podatnika. Ta procedura kontrolna byłaby uruchamiana w przypadku braku informacji lub wątpliwości, jak zinterpretować posiadane dane, a odbywałaby się na zasadzie audytu dokumentów rozliczeniowych;

b) model represyjny, wyznaczający kontroli rolę narzędzia uzyskiwania wysokich dodatkowych wpływów podatkowych i środków

38 Jednolity plik kontrolny (JPK) można zdefiniować jako ujednolicony w skali całego kraju specjalny elektroniczny format danych z dowodów źródłowych, ewidencji księgowych i podatkowych przekazywanych przez zobowiązanych (zob. D. Strzelec, M. Łoboda, Kontrola przestrzegania..., s. 277). 
sanacyjnych, zakładający osiągnięcie wysokiego poziomu dyscypliny podatkowej poprzez zagrożenie karami za ujawnione nieprawidłowości w trakcie kontroli - prewencja represyjna. Rolę taką należy obecnie przypisać kontroli celno-skarbowej prowadzonej przez naczelnika urzędów celno-skarbowych, której zadaniem jest eliminowanie rzeczywistych nadużyć i patologii oraz identyfikacja grup przestępczych. Wprowadzenie takiego wyraźnego podziału na kontrolę o charakterze perswazyjno-audytowym (na podstawie o.p.) oraz z drugiej strony represyjnym (na podstawie ustawy o k.a.s.) uwarunkowane jest możliwością elastycznego przekazywania między naczelnikami urzędów skarbowych a naczelnikami urzędów celno-skarbowych spraw podatkowych zarówno na etapie procedury kontrolnej, jak i postępowania podatkowego ${ }^{39}$. Decyzja w tym zakresie powinna leżeć tylko i wyłącznie po stronie organów podatkowych i opierać się na analizie ryzyka prowadzonej w trakcie danej procedury kontrolnej. Spełnienie tego warunku pozwoli organom podatkowym racjonalnie wykorzystać zasoby ludzkie oraz stosować twardą procedurę kontroli celno-skarbowej jedynie w tych przypadkach, gdy rozmiary, złożoność i stopień oddziaływania potencjalnie występujących uchybień w sposób istotny wpływają na system bezpieczeństwa finansowego państwa.

Za koncepcją jednej procedury kontrolnej w przypadku wyraźnego nakładania się zakresu przedmiotowego przemawia też fakt, że około $80 \%$ czynności kontrolnych w trakcie kontroli podatkowej jest realizowane w siedzibie organu podatkowego zgodnie z art. 285b o.p. Brak jest również możliwości prowadzenia w trakcie czynności sprawdzających postępowania dowodowego w pełnym zakresie (brak odesłania do rozdziału 8 działu III n.o.p.). Ponadto zgodnie $z$ art. $658 \$ 4$ n.o.p. brak zgody zobowiązanego na przedłożenie dowodów w trakcie czynności sprawdzających praktycznie ogranicza możliwość pełnej weryfikacji podstawy opodatkowania przez organy podatkowe, sprowadzając czynności sprawdzające właściwie do formalnej kontroli deklaracji.

$\mathrm{Na}$ marginesie warto jednak wskazać, że przed uzgodnieniami międzyresortowymi w projekcie zgoda na przedłożenie dowodów była wymagana tylko wobec zobowiązanych prowadzących działalność gospodarczą,

39 Zob. art. 18d o.p., który uzależnia przekazanie sprawy od zgody naczelnika urzędu celno-skarbowego oraz braku możliwości wyjaśnienia istotnych okoliczności faktycznych sprawy na podstawie informacji otrzymanych przez organ podatkowy $z$ banku lub innej instytucji finansowej, o których mowa w art. 182 o.p. 
pozostali podatnicy natomiast obligatoryjnie musieliby przedkładać wszelkie dokumenty związane $z$ rozliczeniem zobowiązań podatkowych. Zrównanie wszystkich zobowiązanych bez względu na rodzaj i źródło przychodów pozwalało spełnić wszystkie normy konstytucyjne, a jednocześnie umożliwiło prowadzenie weryfikacji podstawy opodatkowania w ramach czynności sprawdzających jedynie wobec tych zobowiązanych, którzy tego chcą. Uzupełnienie katalogu zakresu czynności sprawdzających o weryfikację podstawy opodatkowania było wyraźnie krytykowane przez większość członków Komisji Kodyfikacyjnej Ogólnego Prawa Podatkowego.

Konkludując powyższe, wskazane argumenty przemawiają za tym, aby zaproponować koncepcję jednej procedury kontrolnej stanowiącej niejako połączenie (hybrydę) obecnych instytucji prawnych: czynności sprawdzających oraz kontroli podatkowej. Nowa procedura kontrolna prowadzona byłaby w dwóch etapach, przy czym drugi z nich byłby uruchamiany w ściśle określonych sytuacjach.

\section{WSTĘPNE POSTĘPOWANIE KONTROLNE}

W ramach pierwszego etapu, nazwanego roboczo wstępnym postępowaniem kontrolnym, czynności prowadzone byłyby wyłącznie w siedzibie organu podatkowego, a jednocześnie nie były objęte limitem czasu trwania kontroli ani innymi ograniczeniami prowadzenia kontroli wynikającymi z Rozdziału 5 ustawy Prawo przedsiębiorców ${ }^{40}$. Czynności wstępnego postępowania kontrolnego wszczynałyby podjęcie faktycznej weryfikacji przez organ podatkowy, wykraczając poza czynności analityczne związane z szacowaniem ryzyka wystąpienia nadużyć podatkowych. Co istotne, cała procedura kontrolna opierałaby się na modelu perswazyjno-audytowym i zawsze poprzedzała właściwe postępowanie kontrolne.

Zakres przedmiotowy tej instytucji, poza jednym istotnym wyjątkiem, byłby praktycznie niezmieniany $\mathrm{w}$ stosunku do obecnie funkcjonujących czynności sprawdzających i obejmowałby: 1) zbadanie terminowości składania deklaracji podatkowych oraz przyczyn jej niezłożenia, pomimo istnienia takiego obowiązku; 2) sprawdzanie terminowości wpłacania zadeklarowanych podatków, w tym również pobieranych przez płatników oraz inkasentów; 3) stwierdzenie formalnej i rachunkowej poprawności dokumentów

${ }^{40}$ Ustawa z dnia 6 marca 2018 r. Prawo przedsiębiorców (tekst jedn. Dz.U. z 2019 r., poz. 1292 ze zm.). 
przedstawionych przy składaniu deklaracji lub wpłacaniu podatków; 4) weryfikację danych i dokumentów przedstawionych przez podatników dokonujących rejestracji podatkowej; 5) weryfikację danych i dokumentów przedstawianych przez podmioty dokonujące zgłoszenia rejestracyjnego uproszczonego, o którym mowa w art. 16b ust. 1 Ustawy z dnia 6 grudnia 2008 r. o podatku akcyzowym; 6) weryfikację prawidłowości sporządzenia remanentu towarów handlowych zarządzonego przez naczelnika urzędu skarbowego w trakcie roku. Organy podatkowe w ramach tej procedury będą mogły dokonać weryfikacji podstawy opodatkowania oraz stwierdzenia formalnej i rachunkowej poprawności dokumentów przedstawionych przy składaniu deklaracji lub wpłacaniu podatków, lecz tylko za zgodą zobowiązanego. Bez takiej zgody organ nie mógłby żądać od zobowiązanych jakichkolwiek dokumentów, z drugiej jednak strony mógłby wszcząć właściwe postępowanie kontrolne. W ramach tej procedury organy podatkowe, po wyrażeniu zgody przez zobowiązanego, mogłyby ustalać stan faktyczny w zakresie niezbędnym do stwierdzenia zgodności z przedstawionymi dokumentami, w tym wzywać zobowiązanych do okazania dokumentów źródłowych stanowiących podstawę dokonanych rozliczeń podatkowych bądź tych mających wpływ na rozliczenie podatku w prawidłowej wysokości. Dozwolone byłoby kierowanie wezwania do kontrahentów lub stron umów cywilnoprawnych innych podmiotów (osób prawnych, jednostek organizacyjnych niemających osobowości prawnej, osób fizycznych prowadzących działalność gospodarczą) do sporządzenia i przekazywania informacji o zdarzeniach wynikających ze stosunków cywilnoprawnych albo z prawa pracy, mogących mieć wpływ na powstanie obowiązku podatkowego lub wysokość zobowiązania podatkowego osób lub jednostek, wobec których prowadzone jest wstępne postępowanie kontrolne, jednakże, co wymaga dodatkowego podkreślenia, za jego zgodą.

W ramach pierwszego etapu tej instytucji prawnej zakres weryfikacji nie obejmowałby (pomimo zgody zobowiązanego) przeprowadzania dowodów z zeznań strony i świadka, opinii biegłych i oględzin oraz procedury badania ksiąg podatkowych, czy też występowania z wnioskami do banków o przekazanie informacji w zakresie rachunków bankowych. Te dowody będą mogły być przeprowadzane jedynie w trakcie właściwego postępowania kontrolnego. Istotne jest, aby ze względu na ekonomikę postępowania wstępne postępowanie kontrolne było jak najmniej uciążliwe i czasochłonne zarówno dla zobowiązanego, jak i organów podatkowych, ale $\mathrm{z}$ drugiej strony należy przestrzegać wszelkich praw zobowiązanych. 
Wszczęcie wstępnej kontroli podatkowej następowałoby w dniu doręczenia wezwania kierowanego do strony (podatnika, płatnika, inkasenta) w celu złożenia wyjaśnień, przedłożenia zgody, o której mowa powyżej, oraz określonych dowodów bądź innych czynności w ramach uprawnień wstępnej kontroli podatkowej lub sporządzenia adnotacji ze spontanicznego stawienia się podatnika w siedzibie organu podatkowego i podjęciu w związku z tym wstępnych czynności kontrolnych. Organ podatkowy sporządzałby jedynie adnotację, a w przypadku ujawnienia nieprawidłowości w rozliczeniach podatkowych bądź okoliczności wskazujących na niezłożenie stosownych rozliczeń, bądź informacji podatkowych, czynności kończyłyby się sporządzeniem projektu deklaracji lub projektu korekty deklaracji (dalej: „predeklaracji”), którą następnie doręczałoby się stronie.

W przypadku złożenia deklaracji podatkowej zgodnej z „predeklaracją" wstępne postępowanie kontrolne zostałoby zakończone, a organ dokonałby stosownej adnotacji. W przypadku natomiast niedokonania korekty rozliczeń w określonym terminie (np. 14 dni od daty otrzymania „predeklaracji”) bądź gdy korekta nie ujmuje wszystkich ustaleń organu i jest niezgodna $\mathrm{z}$ „predeklaracją", organ podatkowy mógłby wszcząć właściwe postępowanie kontrolne lub postępowanie podatkowe.

W celu nadania realności wspierania zobowiązanych w prawidłowym wypełnianiu obowiązków podatkowych oraz nieuciążliwego charakteru wstępnego postępowania kontrolnego, a także nadania swego rodzaju „premii” za dobrowolne samoopodatkowanie, należy rozważyć odstąpienie od obowiązku ustalania wszelkich sankcji administracyjnych (m.in. sankcji w podatku od towarów i usług, k.k.s. ${ }^{41}$, odsetek za zwłokę), o ile podatnik dokonałby korekty zgodnej z „predeklaracją?. Istotne jest również, aby ewentualne wpłaty zaniżonych zobowiązań można było rozłożyć na raty lub odroczyć termin płatności, a wnioski byłyby rozpatrywane na zasadach uproszczonych. Przy dochowaniu przyznanego układu zobowiązany zachowywałby prawo do odstąpienia od nakładania sankcji, o których mowa powyżej. Przy braku złożenia korekt należy przyjąć prawo organu podatkowego do uznania słuszności wszczęcia postępowania podatkowego, bez uprzedniego przeprowadzenia właściwego postępowania kontrolnego.

41 Ustawa z dnia 10 września 1999 r. Kodeks karny skarbowy (tekst jedn. Dz.U. z 2020 r., poz. 19 ze zm.). 
5. WŁaściWe POSTĘPOWANIE KONTROLNE

Właściwe postępowanie kontrolne powinno być z założenia prowadzone poza siedzibą organu podatkowego, m.in. w miejscu prowadzenia działalności gospodarczej, siedzibie, miejscu zamieszkania podatnika (płatnika, inkasenta), miejscu prowadzenia dokumentacji podatkowej, z wyjątkiem przypadku rezygnacji strony z udziału w prowadzonych czynnościach. W ramach tej procedury możliwe byłoby również przeprowadzenie dowodów, których organy podatkowe nie mogłyby prowadzić w trakcie wstępnego postępowania kontrolnego. Dotyczy to przeprowadzenia dowodów z zeznań strony i świadka, opinii biegłych i oględzin oraz procedury badania ksiąg podatkowych, czy też występowania $\mathrm{z}$ wnioskami do banków o przekazanie informacji w zakresie rachunków bankowych. Tym samym zakres właściwego postępowania kontrolnego nie posiadałby ograniczeń zbierania dowodów przypisanych do wstępnego postępowania kontrolnego.

Zakres zbierania dowodów na etapie kontroli właściwej nie ma ograniczeń w stosunku do obecnie obowiązującej procedury kontroli zawartej w dziale VI o.p.; można tylko rozważyć przejęcie pewnych uprawnień wynikających z ustawy o k.a.s. Ta kwestia wymaga jednak szerszej analizy ze względu na założenie wyraźnego rozgraniczenia celu poszczególnych procedur kontrolnych, tj. tej z o.p. oraz kontroli celno-skarbowej.

Wszczęcie właściwego postępowania kontrolnego następowałoby poprzez doręczenie stronie postanowienia o przekształceniu wstępnej kontroli podatkowej we właściwe postępowanie kontrolne. Postanowienie takie czyniłoby również zadość wszelkim wymogom związanym z obowiązkiem organów podatkowych do zawiadomienia kontrolowanego o zamiarze wszczęcia procedury kontrolnej. Właściwe postępowanie kontrolne kończyłoby się poprzez doręczenie stronie protokołu kontroli, która będzie miała prawo złożenia zastrzeżeń do ustaleń w nim zawartych (np. 14 dni), przedstawiając w tym zakresie stosowne dowody oraz korekty deklaracji. O sposobie załatwienia zastrzeżeń strona informowana byłaby przez kontrolujących w terminie 14 dni.

W przypadku stwierdzenia nieprawidłowości w rozliczeniach podatkowych zobowiązany będzie miał prawo do złożenia stosownych korekt deklaracji w określonym ustawowo terminie. Przykładowo można wskazać termin 30 dni od daty otrzymania protokołu kontroli, nie krótszy jednak niż 14 dni od daty otrzymania informacji o sposobie załatwienia złożonych zastrzeżeń. Terminy byłyby liczone od daty doręczenia protokołu. 
Następnie w przypadku dokonania korekt zgodnych z ustaleniami zawartymi w protokole organy podatkowe wydawałyby postanowienie o przyjęciu korekty, co kończyłoby formalnie całość procedury kontrolnej. W przypadku niedokonania korekty rozliczeń we wskazanym terminie bądź gdy w korekcie zobowiązany nie ująłby wszystkich ustaleń, organy podatkowe byłyby zobligowane do wszczęcia postępowania podatkowego.

Kwestią otwartą jest odstąpienie od sankcji administracyjnych i karnych skarbowych na tym etapie postępowania. Ekonomika postępowania przemawia za tym, aby takie odstąpienia były możliwe również na tym etapie, lecz wskazane byłoby ich powiązanie $\mathrm{z}$ zapłatą zaniżonego zobowiązania. Podobnie jest z ewentualną możliwością zabezpieczenia zobowiązań podatkowych na poszczególnych etapach postępowania kontrolnego (wstępne, właściwe). Przyjmując jednak aktualne rozwiązania w tym zakresie, można założyć możliwość zabezpieczenia na etapie kontroli właściwej, natomiast w sprawie przedłużenia terminu zwrotu podatku postanowienia w tym zakresie winny być możliwe na każdym $\mathrm{z}$ etapów tego postępowania.

\section{Podsumowanie}

Wprowadzenie wyraźnego podziału na kontrolę o charakterze perswazyjno-audytowym prowadzonej na podstawie o.p. oraz o charakterze represyjnym na podstawie ustawy o k.a.s. powinno się opierać na spójnej koncepcji zarządzania ryzykiem i zdefiniowaniu miejsca i roli szeroko rozumianej kontroli. W celu wpisania się w trend rozszerzenia zakresu przedmiotowego czynności sprawdzających niezbędna jest zmiana modelu kontroli prowadzonej na podstawie o.p. poprzez połączenie (hybrydę) obecnych instytucji prawnych: czynności sprawdzających oraz kontroli podatkowej. Nowa procedura kontrolna prowadzona byłaby w dwóch etapach, przy czym drugi z nich byłby uruchamiany w ściśle określonych sytuacjach. Przy tworzeniu nowego modelu należy pamiętać o gwarancji wszelkich praw procesowych podatnika oraz ścisłego przestrzegania zasad ogólnych wypracowanych przez Komisję Kodyfikacyjną Ogólnego Prawa Podatkowego wskazaną w rozdziale 2 działu I n.o.p. Bez wątpienia przy redagowaniu konkretnych przepisów ustawowych konieczne jest również odpowiednie wyważenie interesu podatnika i budżetu państwa, tak aby zagwarantować skuteczne realizowanie dochodów budżetowych, ale zawsze z poszanowaniem praw zobowiązanych. 


\section{Bibliografia}

Babiarz S., Dauter B., Hauser R., Kabat A., Niezgódka-Medek M., Rudowski J., Ordynacja podatkowa. Komentarz, Warszawa 2017.

Dzwonkowski H., Czynności sprawdzające - pomoc czy zagrożenie interesów podatnika, „Fiskus” 2006, nr 13/14.

Etel L. et al., Nowa ordynacja podatkowa. Z prac Komisji Kodyfikacyjnej Ogólnego Prawa Podatkowego, Białystok 2017.

Etel L., Dowgier R., Popławski M., Presnerowicz S., Stachurski W., Teszner K., Ordynacja podatkowa. Komentarz, Białystok 2017.

Jagielski J., Kontrola administracji publicznej, Warszawa 1999.

Kubacki R., Ordynacja podatkowa. Kontrola podatkowa, „Przegląd Podatkowy” 1998, nr 5.

Łoboda M., Czynności sprawdzające w Ordynacji podatkowej - stan obecny i kierunki zmian, „Procedury Administracyjne i Podatkowe” 2019, nr 6.

Ordynacja podatkowa. Komentarz praktyczny, red. B. Brzeziński, M. Kalinowski, A. Olesińska, Gdańsk 2015.

Ordynacja podatkowa. Kontrola realizacji zobowiązań podatkowych, red. R. Dowgier, Białystok 2012.

Stachurski W., Realizacja zobowiązań podatkowych $w$ ramach procedur kontrolnych, seria System Prawa Finansowego, t. 3: Prawo daninowe, Warszawa 2010.

Starościak J., Prawo administracyjne, Warszawa 1975.

Strzelec D., Łoboda M., Kontrola przestrzegania przepisów podatkowych, Warszawa 2017.

Wowra J., Kontrola podatkowa i skarbowa przedsiębiorców, Warszawa 2007.

\section{Audit procedures in the Tax Ordinance Act - Current state AND THE DIRECTION OF CHANGES}

Summary. The subject of the article is the answer to the question whether in the case of the recently proposed changes to the subject matter of verification activities, the current model of compliance audit in the Tax Ordinance Act should be maintained. According to the author, after building a coherent concept of risk management and defining the place and role of tax audit as a process, it is possible to propose a concept of a single audit procedure, which is in a way a combination (hybrid) of current legal institutions. The article proposes a general concept of one audit procedure, but consisting of two separate stages, the second of which would be triggered in strictly defined situations. It also points out that when drafting specific legislation, it is necessary to balance the interests of the taxpayer and the state budget in such a way as to guarantee effective implementation of budget revenues, but always with respect for the rights of the obliged parties.

Keywords: audit procedures, new Tax Ordinance Act, verification activities, tax audit 